\title{
Effect of Levels of Boron and Molybdenum on Growth and Yield of Blackgram (Vigna mungo L.)
}

\author{
Karraja Kathyayani", Rajesh Singh and Punnam Chhetri
}

Department of Agronomy, Sam Higginbottom University of Agriculture, Technology and Sciences, Prayagraj, Uttar Pradesh, India

*Corresponding author

Keywords

Blackgram, Boron and Molybdenum

Article Info

Accepted:

12 January 2021

Available Online:

10 February 2021
A field experiment was conducted at Department of Agronomy, Faculty of Agriculture Naini Agricultural Institute, Sam Higginbottom University of Agriculture, Technology and Sciences, Prayagraj, U.P. during kharif2019 on loamy sand soil. The field experiments was conducted to study the Effect of levels of Boron and Molybdenum on Growth and Yield of Blackgram (Vigna mungo L.) and their responses. Treatment T9 (R.D.F $+0.3 \%$ Solution of Borax $+1.5 \mathrm{~kg}$ ha1of Molybdenum) was found best for obtaining the maximum grain yield (19.06 $\mathrm{q} / \mathrm{ha}$ ) and the highest benefit cost ratio was recorded in the treatment T9 (R.D.F + $0.3 \%$ Solution of Borax $+1.5 \mathrm{~kg}$ ha-1 of Molybdenum) which was 1.74:1.

\section{Introduction}

Black gram (Vigna mungo (L.) Hepper) is one of the most important crop grown in India. It is consumed in the form of 'dal' (whole or split, husked and unhusked) or parched. It is chief constituent of 'papad'. It is used as nutritive fodder specially for mulch cattle and also used as green manuring crop. It adds 42 $\mathrm{kg} \mathrm{N}$ ha' 1 in soil. It posses deep root system which binds soil particles and thus, prevent erosion.

Black gram contain about 24 per cent protein, 60 per cent carbohydrate, 10.9 per cent moisture, 1.4 per cent fat, 0.9 per cent fibre,
3.2 per cent minerals and vitamin viz. calcium $154 \mathrm{mg}$, phosphorus $385 \mathrm{mg}$, iron9.1mg and small amount of vitamin B complex. Black gram has been distributed mainly in tropical to subtropical countries.

It is grown in kharif, rabi and summer season in India, Pakistan, Sri Lanka, Burma and some countries of East Asia. In India black gram is very popularly grown in Andhra Pradesh, Bihar, Madhya Pradesh, Maharashtra, Uttar Pradesh, West Bengal, Punjab, Haryana, Tamil Nadu and Karnataka.

In India black gram is grown on 2.99 million ha area with total production of 1.59 million 
tones and productivity of $532 \mathrm{~kg}$ ha'1. In Maharashtra, it occupies an area of 3.65 lakh

ha with total production of 2.06 lakh tones and the productivity of $299 \mathrm{~kg}$ ha'1, while in Marathwada it is grown on an area of 1.47 lakh ha with production of 0.30 lakh tonnes and productivity of $282 \mathrm{~kg}$ ha'1 (Anonymous, 2015).

Boron plays a key role in a diverse range of plant functions including cell wall formation and stability, maintenance of structural and functional integrity of biological membranes, movement of sugar or energy in to growing parts of plants and pollination and seed sets. Adequate $B$ is also required for effective nitrogen fixation and nodulation in legume crops.

Molybdenum is one of the most recognized nutrient elements considered to be essential for the growth of plant also playing important role in structural interring of cell wall and cell membrane and synthesis of protein a well as nitrogen fixation. Legume it plays and additional role in symbiotic nitrogen fixation. The nitrogen fixing enzyme, nitrogenase is compound of molybdenum. Without adequate quantities of this element, nitrogen fixation can't occur.

\section{Materials and Methods}

This experiment was carried out during kharif 2019 at Crop Research Farm, Department of Agronomy, SHUATS, Prayagraj, UP, which is located at $25.28 \mathrm{oN}$ latitude, $81.54 \mathrm{oE}$ longitude and $98 \mathrm{~m}$ altitude above the mean sea level. This area situated on the right side of the river Yamuna by the side of Prayagraj, Rewa Road about $5 \mathrm{~km}$ away from Prayagraj, city. The climate of this region is typically sub-tropical and semi-arid with monsoon commencing by the third week of June and with drawing by end of September. The temperature reached up to $48 \mathrm{oC}$ and in winter it goes down to as low as $2-30 \mathrm{C}$. During the summer hot scorching winds known as "Loo" and frost during winter months are common features. Experimental mechanical analysis of the soil was sand $59.50(\%)$, silt $24.10(\%)$, clay $16.40(\%)$ and textural class silt loam, while chemical analysis of soil was available nitrogen (242 kg/ha), available phosphorus $(24.50 \mathrm{~kg} / \mathrm{ha})$, available potassium $(95.00$ $\mathrm{kg} / \mathrm{ha})$, organic carbon( $0.40 \%), \mathrm{pH}(7.50)$ and $\mathrm{EC}(0.19 \mathrm{dS} / \mathrm{m})$.

Fertilizer application: The fertilizers were applied in each plot according to treatment combinations. T1-R.D.F $+0.1 \%$ Solution of Borax+ 0.5 kgha-1 of Molybdenum, T2R.D.F $+0.1 \%$ Solution of Borax +1.0 kgha-1 of Molybdenum, T3-R.D.F $+0.1 \%$ Solution of Borax +1.5 kgha-1 of Molybdenum, T4R.D.F $+0.2 \%$ Solution of Borax $+0.5 \mathrm{~kg}$ ha1of Molybdenum, T5-R.D.F $+0.2 \%$ Solution of Borax $+1.0 \mathrm{~kg}$ ha-1 of Molybdenum, T6R.D.F $+0.2 \%$ Solution of Borax $+1.5 \mathrm{~kg}$ ha1of Molybdenum, T7-R.D.F $+0.3 \%$ Solution of Borax $+0.5 \mathrm{~kg}$ ha-1 of Molybdenum, T8R.D.F $+0.3 \%$ Solution of Borax $+1.0 \mathrm{~kg}$ ha1of Molybdenum and T9-R.D.F $+0.3 \%$ Solution of Borax $+1.5 \mathrm{~kg}$ ha-1 of Molybdenumwas given in equal quantity to each plot which was calculated on the basis of general recommendation for blackgram as 0 $\mathrm{kg}, 80 \mathrm{~kg}, 100 \mathrm{~kg}$ ha-1 was supplied.

\section{Results and Discussion}

\section{Pre harvest observations}

Table 1 and 2 presents the results for the growth and yield performance of the Blackgram (Vigna mungo L.). Effect of different treatments of Boron and Molybdenum application on pre-harvest observations. The maximum plant height was recorded $(59.77 \mathrm{~cm})$ was recorded with $\mathrm{T} 9$ [R.D.F $+0.3 \%$ Solution of Borax $+1.5 \mathrm{~kg}$ ha- 
1of Molybdenum] followed by $59.43 \mathrm{~cm}$ with T6 [R.D.F $+0.2 \%$ Solution of Borax $+1.5 \mathrm{~kg}$ ha-1of Molybdenum]. T1 [R.D.F $+0.1 \%$ Solution of Borax +0.5 kgha- 1 of Molybdenum] recorded the minimum (55.90 $\mathrm{cm}$ ), maximum number of branches (5.10) was recorded with T9[R.D.F + 0.3\% Solution of Borax $+1.5 \mathrm{~kg}$ ha-1of Molybdenum] followed by 5.00 with T6[R.D.F $+0.2 \%$ Solution of Borax $+1.5 \mathrm{~kg}$ ha-1 of Molybdenum], higher dry weight was observed in T9[R.D.F $+0.3 \%$ Solution of Borax $+1.0 \mathrm{~kg}$ ha-1of Molybdenum] was 2.97 and minimum was (1.93) recorded in T1[R.D.F $+0.1 \%$ Solution of Borax +0.5 kgha- 1 of Molybdenum], maximum Crop
Growth Rate (g/m2/day) (3.69) was recorded with T8 [R.D.F $+0.3 \%$ Solution of Borax + $1.0 \mathrm{~kg}$ ha-1of Molybdenum] followed by 3.28 with T4[R.D.F $+0.2 \%$ Solution of Borax +0.5 $\mathrm{kg}$ ha-1of Molybdenum]. T3[R.D.F $+0.1 \%$ Solution of Borax +1.5 kgha- 1 of Molybdenum] recorded the minimum (0.64) and maximum Relative Growth Rate (g/g/day)(0.069) was recorded with T9 [R.D.F $+0.3 \%$ Solution of Borax $+1.0 \mathrm{~kg}$ ha-1 of Molybdenum] followed by 0.062 with T8[R.D.F $+0.3 \%$ Solution of Borax $+1.0 \mathrm{~kg}$ ha-1of Molybdenum]. T1[R.D.F $+0.1 \%$ Solution of Borax+ 0.5 kgha- 1 of Molybdenum] recorded the minimum (0.040).

Table.1 Effect of Boron and Molybdenum application on pre harvest observations of Blackgram (Vigna mungo L.)

\begin{tabular}{|c|c|c|c|c|c|c|}
\hline Treat & $\begin{array}{c}\text { Plant } \\
\text { height } \\
\text { (cm) }\end{array}$ & $\begin{array}{c}\text { Number of } \\
\text { branches } \\
\text { per plant }\end{array}$ & $\begin{array}{l}\text { Number of } \\
\text { Nodules }\end{array}$ & $\begin{array}{l}\text { Dry weight } \\
\text { (g) }\end{array}$ & $\begin{array}{c}\text { Crop Growth } \\
\text { Rate }\left(g / \mathrm{m}^{2} / \text { day }\right)\end{array}$ & $\begin{array}{c}\text { Relative } \\
\text { Growth Rate } \\
\text { (g/g/day) }\end{array}$ \\
\hline $\begin{array}{l}\text { T1R.D.F+0.1\%ofBorax+0.5kg/ha } \\
\text { of Mo }\end{array}$ & 55.9 & 4.53 & 7.20 & 1.93 & 1.08 & 0.040 \\
\hline $\begin{array}{l}\text { T2-R.D.F + 0.1\% of Borax+1.0 } \\
\text { Kg/ha of Mo }\end{array}$ & 55.43 & 4.90 & 6.80 & 2.13 & 0.96 & 0.047 \\
\hline $\begin{array}{l}\text { T3-R.D.F+ 0.1\% oBorax+1.5kg/ha } \\
\text { of Mo }\end{array}$ & 57.57 & 4.57 & 7.33 & 2.18 & 0.64 & 0.049 \\
\hline $\begin{array}{l}\text { T4-R.D.F+0.2\% of Borax+0.5kg/ha } \\
\text { of Mo }\end{array}$ & 56.77 & 4.97 & 7.67 & 2.21 & 3.28 & 0.052 \\
\hline $\begin{array}{l}\text { T5-R.D.F+0.2\% ofBorax+1.0kg/ha } \\
\text { of Mo }\end{array}$ & 56.2 & 4.90 & 7.55 & 2.23 & 2.23 & 0.051 \\
\hline $\begin{array}{l}\text { T6-R.D.F+0.2\%ofBorax+1.5kg/ha } \\
\text { of Mo }\end{array}$ & 59.43 & 5.00 & 8.77 & 2.64 & 2.39 & 0.062 \\
\hline $\begin{array}{l}\text { T7-R.D.F+0.3\%ofBorax+0.5kg/ha } \\
\text { of Mo }\end{array}$ & 57.47 & 4.97 & 8.10 & 2.17 & 2.27 & 0.050 \\
\hline $\begin{array}{l}\text { T8-R.D.F+0.3\% ofBorax+1.0kg/ha } \\
\text { of Mo }\end{array}$ & 57.33 & 4.77 & 8.43 & 2.61 & 3.69 & 0.062 \\
\hline $\begin{array}{l}\text { T9-R.D.F+0.3\%ofBorax+1.5kg/ha } \\
\text { of Mo }\end{array}$ & 59.77 & 5.10 & 9.67 & 2.97 & 2.17 & 0.069 \\
\hline F- test & $\mathrm{S}$ & $\mathrm{S}$ & $\mathrm{S}$ & $\mathrm{S}$ & NS & $\mathbf{S}$ \\
\hline S. Ed. $( \pm)$ & 1.076 & 0.154 & 0.509 & 0.278 & 2.626 & 0.008 \\
\hline C. D. $(P=0.05)$ & 2.221 & 0.318 & 1.05 & 0.573 & 5.419 & 0.017 \\
\hline
\end{tabular}


Table.2 Effect of Boron and Molybdenum application on post harvest observations of Blackgram (Vigna mungo L.)

\begin{tabular}{|c|c|c|c|c|c|c|}
\hline Treat & $\begin{array}{l}\text { Number of } \\
\text { pods per } \\
\text { plant }\end{array}$ & $\begin{array}{l}\text { Number } \\
\text { Seeds/pod }\end{array}$ & $\begin{array}{c}\text { Test } \\
\text { weight } \\
\text { (g) }\end{array}$ & $\begin{array}{l}\text { Seed yield } \\
\text { (q/ha) }\end{array}$ & $\begin{array}{l}\text { Straw yield } \\
\quad(\mathbf{q} / \mathrm{ha})\end{array}$ & $\begin{array}{l}\text { Harvest } \\
\text { inde }(\%)\end{array}$ \\
\hline $\begin{array}{l}\text { T1R.D.F+0.1\%ofBorax+0.5kg/ha } \\
\text { of Mo }\end{array}$ & 18.43 & 5.93 & 28.83 & 6.51 & 14.41 & 45.18 \\
\hline $\begin{array}{l}\text { T2-R.D.F }+0.1 \% \text { of Borax }+1.0 \\
\text { Kg/ha of Mo }\end{array}$ & 22.23 & 6.63 & 30.63 & 7.64 & 16.68 & 45.8 \\
\hline $\begin{array}{l}\text { T3-R.D.F+ 0.1\% } \\
\text { oBorax+1.5kg/ha of Mo }\end{array}$ & 24.23 & 7.03 & 32.03 & 8.47 & 17.99 & 47.08 \\
\hline $\begin{array}{l}\text { T4-R.D.F+0.2\% of } \\
\text { Borax+0.5kg/ha of Mo }\end{array}$ & 26.03 & 7.43 & 33.13 & 9.08 & 18.76 & 48.4 \\
\hline $\begin{array}{l}\text { T5-R.D.F+0.2\%ofBorax+1.0kg/ha } \\
\text { of Mo }\end{array}$ & 25.63 & 7.33 & 32.93 & 8.58 & 17.93 & 49.06 \\
\hline $\begin{array}{l}\text { T6-R.D.F+0.2\%ofBorax+1.5kg/ha } \\
\text { of Mo }\end{array}$ & 26.83 & 7.63 & 33.5 & 9.08 & 18.76 & 47.85 \\
\hline $\begin{array}{l}\text { T7-R.D.F+0.3\%ofBorax+0.5kg/ha } \\
\text { of Mo }\end{array}$ & 23.33 & 6.73 & 31.13 & 8.02 & 17.23 & 46.55 \\
\hline $\begin{array}{l}\text { T8-R.D.F+0.3\% ofBorax+1.0kg/ha } \\
\text { of Mo }\end{array}$ & 26.4 & 7.53 & 33.23 & 8.83 & 18.21 & 48.49 \\
\hline $\begin{array}{l}\text { T9- } \\
\text { R.D.F }+0.3 \% \text { ofBorax }+1.5 \mathrm{~kg} / \mathrm{ha} \mathrm{of} \\
\text { Mo }\end{array}$ & 27.03 & 7.8 & 33.53 & 9.35 & 19.06 & 48.4 \\
\hline F- test & $\mathrm{S}$ & $\mathrm{S}$ & $\mathrm{S}$ & S & $\mathrm{S}$ & $\mathbf{S}$ \\
\hline S. Ed. $( \pm)$ & 1.155 & 0.292 & 0.923 & 0.483 & 0.57 & 1.114 \\
\hline C. D. $(P=0.05)$ & 2.383 & 0.602 & 1.905 & 0.996 & 1.176 & 2.299 \\
\hline
\end{tabular}

$\mathrm{V}$ The increase in plant height by the basal application of $\mathrm{B}, \mathrm{Mo}$ and $\mathrm{Ni}$ might be due to its crucial role as promoter of cell division and act in the induction and development of its meristematic tissues. The results were in conformity with the findings of Devi et al., (2012) and Alam et al., (2017) in soybean and chickpea with B nutrition, Tahir et al.,(2014) in blackgram with Mo and Valenciano et al., (2010) in chickpea with B+Mo nutrition. This greater increase in branch number with $\mathrm{B}$, Mo and $\mathrm{Ni}$ application in combinations could be attributed to the increase in plant height caused by the three nutrients. These results were in concurrence with the findings of Rahman et al., (2008) Alam et al., (2017)
Devi et al., (2012), Malik et al., (2015) and (Shil et al., 2007), who reported the increase in branching with supplementation of these three micronutrients. Alam et al., (2017) reported the highest nodule number with application of $3 \mathrm{~kg} \mathrm{~B}$ ha-1 in chickpea. Awomi et al., (2012) found maximum number of nodules in mungbean with the application of Mo @ $1.5 \mathrm{~kg}$ ha-1. Khan et al., (2014) stated that application of nickel up to $10 \mathrm{ppm}$ increased the functional nodules number in chickpea. Similar positive effects of B and Mo on TDM have also been reported by Malik et al., (2015) in mungbean, Karpagam and Rajesh (2014) in blackgram, Zahoor et al., (2013) in soybean and Goutam 
et al., (2014). The results of present investigation also exposed the same. Mahilane and Singh (2018) reported that application of Mo significantly increased the CGR of blackgram when applied @ $1.0 \mathrm{~kg}$ ha-1. Similar observations of increase in CGR in response to $\mathrm{B}$ and Mo application were reported by Sritharan et al., (2015) in blackgram and Wasaya et al., (2017) in maize.

\section{Post-harvest observations}

Data presented in table 2 showed that treatment T9[R.D.F $+0.3 \%$ Solution of Borax $+1.5 \mathrm{~kg}$ ha-1of Molybdenum] recorded maximum number of pods per plant (27.03), followed by (26.83) in T6[R.D.F $+0.2 \%$ Solution of Borax $+1.5 \mathrm{~kg}$ ha-1 of Molybdenum]. Lower number of pods per plant was found in treatment T1[R.D.F + $0.1 \%$ Solution of Borax+ 0.5 kgha- 1 of Molybdenum] was (18.43) number of pods per plant. Treatment T9[R.D.F $+0.3 \%$ Solution of Borax $+1.5 \mathrm{~kg}$ ha-1of Molybdenum] recorded maximum seeds per pod (7.80), followed by (7.63) in T6[R.D.F + $0.2 \%$ Solution of Borax $+1.5 \mathrm{~kg}$ ha- 1 of Molybdenum] and minimum number of seed per pod was found in treatment T1[R.D.F + $0.1 \%$ Solution of Borax +0.5 kgha- 1 of Molybdenum] was (5.93) seeds/pod. Treatment T9 [R.D.F + $0.3 \%$ Solution of Borax $+1.5 \mathrm{~kg}$ ha-1 of Molybdenum] recorded maximum test weight (33.53), followed by (33.50) inT6[R.D.F + 0.2\% Solution of Borax $+1.5 \mathrm{~kg}$ ha-1of Molybdenum]. Lowest test weight was found in treatment T1[R.D.F + $0.1 \%$ Solution of Borax+ 0.5 kgha- 1 of Molybdenum] was 28.83 test weight. Treatment T9[R.D.F $+0.3 \%$ Solution of Borax $+1.5 \mathrm{~kg}$ ha-1 of Molybdenum] recorded maximum Seed yield ( $\mathrm{q} / \mathrm{ha}$ ) (9.35), followed by (9.08) in T6[R.D.F $+0.2 \%$ Solution of Borax $+1.5 \mathrm{~kg}$ ha-1of Molybdenum] and minimum. Seed yield $(\mathrm{q} / \mathrm{ha})$ was found in treatment T1[R.D.F $+0.1 \%$ Solution of Borax+ 0.5 kgha-1 of Molybdenum] was (6.51) Seed yield (q/ha). Treatment T9[R.D.F $+0.3 \%$ Solution of Borax $+1.5 \mathrm{~kg}$ ha- 1 of Molybdenum] recorded maximum Straw yield (q/ha) (19.06), followed by (18.76) in T6[R.D.F $+0.2 \%$ Solution of Borax $+1.5 \mathrm{~kg}$ ha-1of Molybdenum]. Lowest Straw yield (q/ha)was found in treatment T1[R.D.F + $0.1 \%$ Solution of Borax+ 0.5 kgha- 1 of Molybdenum] was 14.41Straw yield (q/ha). Treatment T5 [R.D.F $+0.2 \%$ Solution of Borax $+1.0 \mathrm{~kg}$ ha-1 of Molybdenum] recorded maximum harvest index (\%) (49.06), followed by (48.49) in T8[R.D.F $+0.3 \%$ Solution of Borax $+1.0 \mathrm{~kg}$ ha-1of Molybdenum]. Lowest harvest index (\%) was found in treatment T1[R.D.F $+0.1 \%$ Solution of Borax +0.5 kgha-1 of Molybdenum] was (45.18) harvest index (\%). These results were in concurrence with the findings of Duyingqiong et al., (2002), Rathi. (2016), Chatterjee et al., (1985) and Bagewadi et al., (2003) who reported the significant increase in pod number per plant in blackgram. The increase in seed number could be due to the increase in pod length caused by the three nutrients. The results of the present investigation were in conformity with the findings of (Alam et al., 2017), Pandey and Gupta, (2012) and Alam and Islam, (2016) who reported these three nutrients increased seed number perpod. The results of present investigations in contrasting with the findings of Alam and Islam, (2016), Ramamoorthy and Sudarshan, (1992) and Monem et al., (2009) who reported B, Mo influenced the 100 seed weight. Working with different crops other researchers have also reported increased yield with application of B (; Rajeev and Dinesh, 2014) and other micronutrients Mo(Kumar et al., 2018; Malik et al., 2015). However the essential role of Borax and molybdenum has been established as a component of several enzymes concerned with carbohydrate and nitrogen metabolism, in addition to its 
involvement directly or indirectly in regulating the various physiological processes of plants. Similar results were reported by Sharma et al., (2010).

\section{References}

Alam, M. S., Ali, K. J and Hoque, A. (2017). Yield and Yield Component of Chickpea as Affected by Boron Application. Journal of Experimental Agriculture International. 15(2): 1-9.

Awomi, T. A., Singh, A.K., Kumar, $M$ and Borodoloi, L. J. (2012). Effect of Phosphorus, Molybdenum and Cobalt Nutrition on Yield and Quality of Mungbean (Vigna radiata L.) in Acidic Soil of Northeast India. Indian Journal of Hill Farming. 25(2): 22-26.

Devi, K. V., Singh, M. S., Singh, S.B and Singh, K. K. (2012). Influence of Sulphur and Boron Fertilization on Yield, Quality, Nutrient Uptake and Economics of Soybean (Glycine max) under Upland Conditions. Journal of Agricultural Science. 4(4): 1-10.

Gautam, S., Pandey, S. N and Srivastava, M. N. (2014). Effect of $\mathrm{Ni}$ on seedling growth, physiological attributes in black gram (vigna mungo) in leaves. InternationalJournal of Current Research. 6(9): 8673-8676.

Karpagam, J and Rajesh, N. (2014). Molybdenum Application for Enhancing Growth, Yield and Soil Health on Green Gram (Vigna radiata L.). American-Eurasian Journal of Agricultural \& Environmental Sciences. 14 (12): 1378-1381.

Khan, K and Prakash, V. (2014). Effect of rhizobial inoculation on growth, yield, nutrient and economics of summer urdbean (Vigna mungo L.Hepper) in relation to zinc and molybdenum. International Journal of Advanced Research in Chemistry and Chemical
Engineering. 1(1): 1-10.

Khan, N., Tariq, M., Ullah, K., Muhammad, D., Khan, I., Rahatullah, K., Ahmed, N and Ahmed, S. (2014). The Effect of Molybdenum and Iron on Nodulation, Nitrogen and Yield of Chickpea Genotypes (Cicer Arietinum L). Journal of Agriculture and Veterinary Science. 7(1): 63-79.

Mahilane, C and Singh, V. (2018). Effect of Zinc and Molybdenum on Growth, Yield Attributes, Yield and Protein in Grain on Summer Blackgram (Vigna mungo L.) International Journal of Current Microbiology and Applied Sciences.7(1):1156- 1162.

Malik, K., kumar, S and Arya, K. P. S. (2015). Effect of zinc, molybdenum and urea on growth and yield of mungbean (Vigna radiata L. Wilczek). Advance research journal of crop improvement. 6(1): 59-65.

Rahman, M. M., Bhuiyan, M.M.H., Sutradhar, G.N., Rahman, C.M.M and Paul, A.K. (2008). Effect of phosphorus, molybdenum and rhizobium inoculation on yield and yield attributes of mungbean. International journal of sustainable crop production. 3(6): 26-33.

Shil, N. C., Noor, S and Hossain, M. A. (2007). Effects of Boron and Molybdenum on the Yield of Chickpea. Journal of Agriculture \& Rural Development. 5(1\&2): 17-24.

Sritharan, N., Rajavel, M and Senthilkumar, R. (2015). Physiological approaches Yield improvement in blackgram. Legume Research. 38(1): 91-95.

Tahir, M., Sher, A and Majeed, M. A. (2014). Effect of Molybdenum on yield and quality of blackgram (Vigna mungo (L.) Hepper) . Pakistan journal of life and social sciences. 12(2): 101-105.

Valenciano, J. B., Boto, J. A and Marcelo, V. (2010). Response of chickpea (Cicer 
arietinum L.) yield to zinc, boron and molybdenum application under pot conditions. Spanish Journal of Agricultural Research. 8(3): 797-807.

Wasaya, A., Shabir, M. S., Hussain, M., Ansar, M., Aziz, A., Hassan, $\mathrm{W}$ and Ahmad, I. (2017). Foliar application of Zinc and Boron improved the productivity and net returns of maize grown under rainfed conditions of Pothwar plateau. Journal of soil science and plant nutrirtion.17(1):1-10.

Zahoor, F., Ahmed, M., Malik, M. M., Mubeen, K., Siddiqui, M. H., Rashee, M., Ansar, R and Mehmood, K. (2013). Soybean (Glycine max L.) response to micro-nutrients. Turkish Journal of Field Crops. 18(2): 134-138.

\section{How to cite this article:}

Karraja Kathyayani, Rajesh Singh and Punnam Chhetri. 2021. Effect of Levels of Boron and Molybdenum on Growth and Yield of Blackgram (Vigna mungo L.). Int.J.Curr.Microbiol.App.Sci. 10(02): 339-345. doi: https://doi.org/10.20546/ijcmas.2021.1002.039 